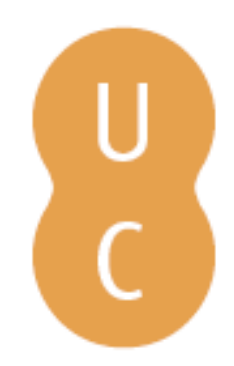

\title{
nombalina
}

Introcuction: a new humanism is needed ... the expansion of consciousness and brotherhood are vital

Autor(es): $\quad$ Oliveira, Albertina L.

Publicado por: Imprensa da Universidade de Coimbra

URL

persistente: URI:http://hdl.handle.net/10316.2/32475

DOI: $\quad$ DOI:http://dx.doi.org/10.14195/978-989-26-0732-0_1

Accessed : $\quad$ 26-Apr-2023 14:10:15

A navegação consulta e descarregamento dos títulos inseridos nas Bibliotecas Digitais UC Digitalis, UC Pombalina e UC Impactum, pressupõem a aceitação plena e sem reservas dos Termos e Condições de Uso destas Bibliotecas Digitais, disponíveis em https://digitalis.uc.pt/pt-pt/termos.

Conforme exposto nos referidos Termos e Condições de Uso, o descarregamento de títulos de acesso restrito requer uma licença válida de autorização devendo o utilizador aceder ao(s) documento(s) a partir de um endereço de IP da instituição detentora da supramencionada licença.

Ao utilizador é apenas permitido o descarregamento para uso pessoal, pelo que o emprego do(s) título(s) descarregado(s) para outro fim, designadamente comercial, carece de autorização do respetivo autor ou editor da obra.

Na medida em que todas as obras da UC Digitalis se encontram protegidas pelo Código do Direito de Autor e Direitos Conexos e demais legislação aplicável, toda a cópia, parcial ou total, deste documento, nos casos em que é legalmente admitida, deverá conter ou fazer-se acompanhar por este aviso.

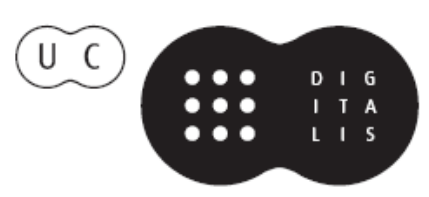


MPRENSA DA

UNIVERSIDADE

DE COIMBRA

COIMBRA

UNIVERSITY

- PRESS 


\section{INTRODUCTION: A NEW HUMANISM IS NEEDED... THE EXPANSION OF CONSCIOUSNESS AND BROTHERHOOD ARE VITAL}

Albertina L. Oliveira ${ }^{1}$

This book is grounded on the basic idea that to promote people's quality of life and increase well-being, we need to face life in all its extension and to involve all individuals, in the most diverse contexts, in learning processes and active aging, increasingly intentional and conscious. It implies that we are able to reflect on the consequences of our acts, in ourselves, in the communities we relate to (family, school, workplace, recreation, culture, leisure time, etc.), in the society to which we belong and in the global world we share.

The challenges and the complexity of the problems at a national and international level are huge, but so are the forces of renewal and reinvention. We need a strong commitment to the construction of fairer societies, more fraternal, more genuine, more open to processes and dynamics of cooperation, not competition; more inclusive and able to stimulate the vast potential that all human beings have for good, more committed to life and the respect for life - the great master who embraces us and who presents, more directly or subtly, growth challenges in order to become better people - able to promote our development and that of the communities in which we participate. Is it possible to develop this

\footnotetext{
${ }^{1}$ Faculty of Psychology and Educational Sciences, University of Coimbra, Portugal; Centro de Estudos Interdisciplinares do Século 20 (CEIS20).

Email: aolima@fpce.uc.pt
} 
attitude and get involved in conscious and intentional actions without increasingly and reflexively adopting a broad perspective? We do not believe that! Opening up to a comprehensive and in-depth consideration of life is both galvanizing and liberating. In conceptual and scientific terms, the joint and irreversible movement of, on the one hand, breaking/ dissolving prejudices and on the other of affirming the great potential of the human being, has intensified in the second half of the 20th century. Not as a mere abstract idea, but as something observably tangible. From Psychology and Education came wafts of fresh air that have helped to renew the conceptions about the human being abilities and to reconsider the essential and deep sense of education.

In the field of Psychology, a mark is the research work started by Schaie (1996), in 1956, about adults' intellectual development, which gave consistent evidence that adulthood and old age, although with undeniable losses, are also a time of development where gains take place and where the learning ability remains preserved in most people (Baltes \& Mayer, 1999). Such work is part of the new concept of development across the lifespan. However, as writes Simões (2002), "it seems that we haven't woken yet to the new reality of the elderly and we insist on perceiving and judging them based on myths and stereotypes" (p. 560). And because educational institutions also need to situate themselves in an evolutionary perspective and to contribute to clarifying and forming, the Faculty of Psychology and Educational Sciences of the University of Coimbra included in its first master course (in Educational Sciences), for the first time (1992), the discipline of Adult Psychology, directed by Professor António Simões, a pioneer in the scientific study of adult and the elderly subjects (Lima, 2011). This field of study and others that followed, such as the beginning of the lecturing of Adult Education in the academic year 1993/1994 (in the context of the degree in Educational Sciences), along with many other later developments, represent the contribution and commitment of a university institution in the service of building a more enlightened society, less susceptible to the influence of prejudices, enriched with human beings driven by ideals of justice, health, solidarity and nobility of spirit. 
These are precisely the key aspects of any truly educational project. In this context, and in accordance with the educational approach, each 'step' of life "must be understood as a successive construction, as a result of the process of integration of experiences and none can be considered as a final phase of change and development" (De Natale, 2003, p.13). In this regard, we share the position of the author that it is more appropriate to speak of "life course" than "lifelong", and we cannot agree more with Romano (1957, cit. by De Natale, 2003, p. 30) when he says that "life cannot be a mass of periods, but a totality that takes sense from all its phases and their intimate interaction".

In a kind of conjugate movement, if we go back almost to the beginning of the second half of the 20th century, we find the dawn of social affirmation of the importance of Permanent Education (through the UNESCO International Conference on Adult Education initiated in 1949), which converges with the data from psychological research on enhancement of adult capacities, particularly learning ability, assuming openly that the human being is characterized by incompleteness (neoteny). There is no stage in life where human beings reaches "full development of their full potential" (Simões, 1979a, p. 58), and that's why the construction of human beings in the framework of the Permanent Education "would not be a time of life, but a dimension of life" (Simões, 1979b, p. 46). It is not only "continuity in time" as "an unfolding of educational activities throughout the lifespan" but also "continuity in space" (living spaces of the individual: external and internal).

Although it is possible to find in the remotest parts of history the idea of Permanent Education, considering only the Western world, is in the late $18^{\text {th }}$ century that usually the emergence of the concept is situated with the Condorcet Report, dated 1792, on the General Organization of Public Instruction in France (Oliveira, 2005). This remarkable document, at the same time as launching modern education systems, assigning to the State the responsibility for being the guarantor of "education for all", explicitly deals with the need for education "beyond school" (Osorio, 2005, p. 16). However, only in the early years of the seventies of the last 
century were the discourse and practice of Permanent Education ${ }^{2}$ launched, driven by the work of Legrand (1969), "The meaning of lifelong education", jointly with several documents of the Council of Europe (1970), the work of Schwartz (1973) and of OECD (1973). In this regard the Report of the International Commission for the Development of Education stands out, coordinated by Edgar Faure (1972), "Apprendre à être" [Learning to be], and the work of Dave (1976/1979), "Foundations of lifelong education". The same kind of conceptual elaboration is founded in Portugal in "Permanent education and teacher training" (Simões, 1979b).

Thus, Permanent Education not only enshrines the right of all people to learn throughout their life, nor only the idea that it is the key to educational society, and means even less an educational sector, but it must be necessarily thought as the principle underlying the organization of a global educational system (Faure et al., 1972). With universalist thinking and looking for bridges beyond Western culture, Dave (1976/1979) helps us to realize that the Permanent Education' project has solid roots in universal history, which we need to rehabilitate in an increasingly intentional, determined and conscious manner. In this remarkable work we can find what is of great actuality:

the fundamental purpose of lifelong education must coincide with a new humanism, of a global character, which will be based on a synthesis of knowledge and common sense, of humanity and science, of rationality and mystery, placing man in the centre of the dynamic process of change and enabling him to retain his value and dignity as creator of knowledge or as sole arbiter of its implementation. To the creative capacity, we must add the quality of discrimination and the virtue of 'prudence' that the Buddha recommended to his disciples. Only in this way can we situate man's spirit at the centre of the planetary civilization of tomorrow and win the present crisis to which we already have alluded. Humanism

\footnotetext{
2 The English version for this expression is lifelong education. However, we intentionally chose to use the direct translation of the French or Portuguese language - Educação Permanente -, because it better captures the horizontal and vertical dimensions of the concept as it was conceptualized in the seventies of 20 th century by several authors.
} 
requires a unifying core values. To what extent does history afford this central core? In other words, to what extent can history help to ground the foundations of a Lifelong Education? (p. 126).

Surely you will agree that depends on all of us!

It is true that education doesn't make everything, and it cannot be assumed as the panacea for all the problems that affect mankind (Lima, 2010a), but without it we are doomed to remain in a limbo of obscurity and ignorance that feed injustice, inequality, hatred and violence - obstacles to development in man nobility of spirit. As Riemen (2011) states, referring us to the thought of philosopher Whitman, the nobility of spirit "is the realization of true freedom" and adds that "a system, political institutions, and the right to vote are not in themselves sufficient for true democracy ... the aim of democracy is that the most profound freedom becomes law, and then will follow the good and virtue" (p. 29). Nobility of spirit urges that we can "model [our] life in accordance with strict and noble life principles" (p. 37), as did, for example, Baruch Spinoza. It behooves us all to develop a deep humanism, through education, and to act by integrating and transforming people, institutions, political systems, nations, by establishing wisdom, brotherhood and a critical attitude, able to question the reigning ethos of economic imperialism and competitiveness (Zarifis \& Gravani, 2014). There do not seem to exist viable pathways far from this way! This work arises from a serious commitment to these values, which at a certain point merged in the PALADIN project and in the organisation of an International Conference that led to the chapters of this book.

\section{From the origin of a project (PALADIN) to the edition of an e-book}

Like many other creative ideas the PALADIN project (Promoting Active Learning and Aging of Disadvantaged Seniors) was born in a classroom of the Faculty of Psychology and Educational Sciences (University of Coimbra), Education for autonomy and self-directed learning, within the 
Master course of Adult Education and Community Intervention. The challenge was launched to the doctoral candidate, later general coordinator of the PALADIN, Teresa Pinto - of planning a work project inspired by the programmatic contents of the area of study mentioned. Her vast experience in European projects and her talent for capturing fundamental ideas of an academic curriculum and transforming them into a creative, complex and ambitious project, requiring multiple articulations of institutions of several European countries, led to the funding of the project, and two years later, to the evaluation of excellent obtained from the European Commission ${ }^{3}$.

PALADIN's central ideas do not stray from the main principles - on the contrary strengthen and consolidate them - that have always guided the field of adult education (Oliveira et al., 2011), seen as subsystem of Permanent Education, even though it integrates plural streams of conceptualization, not infrequently coming from contradictory epistemological roots, raising and maintaining attractions worthy of enchantment and simultaneously of inflamed debates and controversies.

The latitudes and longitudes of this domain of theorization, research and practice are of a huge vastness, contemplating in itself 'regions' and phenomena of a significant diversity, of different natures, of expression in contexts, levels and modalities strongly heterogeneous.

With the thesis of adultism deposed (Simões, 1979a) in terms of longitude, it is increasingly difficult to define the contours of adulthood from the viewpoint of ontogenesis. Although in traditional society there were no major doubts when distinguishing childhood, adulthood and old age, currently, considering scientific advances, the complexity of life in the so-called postmodern societies and the ever-increasing life expectancy, the contours are ever more tenuous and a conceptual differentiation of new stages has been emerging. For illustrative purposes let us consider the period of emerging adulthood (Arnett \& Tanner,

\footnotetext{
3 Many resources have been produced for the elderly (see: http://projectpaladin.eu/) and it is worth noting the Self-Efficacy for Self-Directed Learning Scales (in five areas: health, activity, citizenship, education and finances) and the Self-efficacy and worthy old age memorandum, translated into 22 European languages.
} 
2008; Ferreira \& Jorge, 2008) proposed in the 90s of the last century, as a result of the more incisive exploration of identity that young people tend to make (between 18 and 25 years old), entailing in particular areas such as love, work and education. In general, these young people do not consider themselves teenagers but neither do they see themselves as adults, nor does society expect them to perform social roles such as those required of the latter (Dias, 2012). At the other age pole we find elderly people. However, we cannot assign any intrinsic meaning to that special age category, except for a chronological criterion "serving [only] to socially organize our lifecycle and the events that take place across it" (Lima, 2010b, p. 39), as for instance the retirement age, which varies from society to society and is nothing more than anstract and normative construction. As Simões states (1990), "in reality, the elderly simply does not exist" (p. 109), and it is possible to be "physically old, psychologically in middle-age and socially young or a different combination of these three situations" (p. 110). This brings us to the notion that human development is done on a continuous basis and that, strictly speaking, there is no aging in the first person, but only in the plural ('agings') (Lima, 2010b).

However, it is still common for several ages of life to be distinguished, old age being a stage of adulthood upon which each Portuguese citizen enters at 65 years old, and which raises a number of specific challenges requiring expertise from multiple areas of knowledge, that is, a multi-disciplinary approach to the elderly (Paúl \& Ribeiro, 2012). If we bear in mind that growing older is associated with an increasing heterogeneity, which still translates into more complexity (taking into account differences in terms of the biological, functional, psychological and social criteria) and that increased longevity is a consistent and world spanning phenomenon, the differentiation of age subgroups within advanced adulthood is understandable. In fact, as early as 1976, Neugarten pointed out this need, and three groups came to be distinguished: the young-old (people aged 65-74), the middle-old (75-84) and the old-old (85 and over) (Simões, 2006). Currently, going even further, studies with centenarians are already numerous (Poon et al., 2007). 
Precisely because more advanced ages of life have been attracting increasing interest, and because there is an increasing need to prepare people, society and the various professionals to deal with the aging process, in the context of Gerontology and in the framework of the Permanent Education, Educational Gerontology is assumed as an area of growing importance (Simões, 1999). This isn't the appropriate place for a conceptual reflection on the object of study of this discipline, but we totally agree with Sherron and Lumsden (1978) when they state that "in seeking the unique contribution that education can make to the field of gerontology, we immediately reach the heart of the matter - that the last of life is populated by more than problems and decline. The final stages of life are an opportunity for integration or summing up, for seeking the meanings that have been avoided or postponed. Education can be a means of facilitating this reflection and insight" (p. 2). It is also worth noting, as Vieira and Perista (2012) assert, that "it remains open a long avenue for future research if the objective is the promotion of an effective active aging for both women and men" (p. 11).

It is our wish that the various chapters that make up this book may contribute to enriching the field of Gerontology, provide valuable knowledge for all those interested in the problem of aging and give rise to thoughts that inspire conscious, solidary and truly educational actions.

\section{Presenting the chapters}

The first chapter of this book Possibilities and limitations of age presents a very well documented overview of the vast potentials and limitations associated with the aging process. Professor Fernández- Ballesteros, reviewing many of the most important empirical data that researchers around the world have produced, including her own substantial investigations, helps us understand that the aging process is very complex, challenge and heterogeneous and that we need to take into consideration many influential factors such as biology, the individual agency and the interactions of the person with the sociocultural context, to name just a 
few. The chapter also strongly highlights that all of us at the individual, societal or global level must fight the still deeply ingrained stereotypes about the aging process and old age.

In a broad and bright reflection on the concept of meaning of life, Daniel Serrão raises the issues that echo from the ends of time. Starting from biological phenomena and from various levels of attribution of meaning (aesthetic, ethical and rational meaning) the author stresses that the deeper sense attributed to human life is of symbolic immortality or of hope. He draws also attention to the need to educate for the terminal body life time (the first topic for pedagogy on dying), so that this stage of life is seen as "a significant time to the person". And, reaffirming the need for a deeply humanist perspective and education for death, the Professor concludes: "Caring for another, who is going to die, is work of the highest dignity that demands the possession of the greatest human virtues, without which the carer will not attain the primordial end - which is that of generating inner peace within those who are going to die".

Going beyond demographic statistical data, the chapter Who is a disadvantaged senior in Europe? Main identifiers for assessing efficacy for self-directed learning of those being aged and at risk proposes considering issues of access, active citizenship, gender equality, career development and career change, but also enjoyment of participation in learning as crucial factors in locating identifiers for disadvantaged seniors in Europe. The main message is that older people cannot be excluded from education and learning. All the studies, including PALADIN ones (Oliveira et al., 2012), show that people with higher levels of education reveal a greater agency and a greater healthy aging: they are more active, participative, productive and healthy.

In Reflections from a study about wisdom with students from a Senior University, the importance of being an intentional learner even beyond retirement age is underlined. The reports of the participants let us describe a retirement actively lived, with daily and weekly routines, similar to the rhythms of life before retirement. These seniors fought to have a healthy life and considered themselves useful for their family and friends and others, particularly through voluntary activities. 
In Relationships and intergenerational solidarities - social, educational and health challenges, the author focuses her reflection on the development of new relationships and forms of intergenerational solidarity within the family and within society at large, where different generations may contribute towards a culture of solidarity, inclusiveness and citizenship.

In another reflection about Intergenerational Solidarity: bringing together social and economic development, a proposal is presented pointing to the need for a more integrated approach to generations in order to build policies and programs that promote social and economic development, conceived not as an end in itself but as a means of achieving greater well-being.

Still approaching the same issue, Intergeneration education as a strategy for promoting active aging: analyzing the needs of a local community as a way to develop relevant and sustainable projects of intervention is a chapter that focuses on the importance of intergeneration education programs. The authors emphasize that they ought to be built through a realistic identification of the needs and potentialities of the local communities.

The IPL 60+ Program: a singular case of senior education in an intergenerational context presents a Senior Education Program designed for adults over 50 years old. Its mission is to help change the aging paradigm through the stimulation and promotion of formative, educational and socio-cultural activities that involve individuals in their own learning path and lifelong development, always in a context of intergenerational sociability.

Life histories and intergenerational knowledge transference: a case study at the Banco do Nordeste corporate university presents the main results of learning experiences and life stories within a program in succession at the Bank of the Northeast Corporate University in Brazil. The important role of the instructors, peers and the institution is emphasized.

Elderly \& ICT: A need and urgency for an effective info-inclusion highlights the need for citizens to be digitally literate in order to deal with and use those technologies as a routine of their everyday life. The aim of this chapter is to discuss the main initiatives carried out and to 
present the main obstacles, advantages, and some clues for the use of ICT by elderly people.

Moving to a pragmatic perspective, Senior students in the knowledge society: a curricular program of digital literacy presents a proposal to offer ICT training to a senior audience, based on a 3-academic-year informatics course. The authors stress that besides the specific profile of aged students, which requires specific methodological choices, there is the need to frame the course contents taking into consideration the needs and interests of each student.

Centred on the experiences of professionals that care for older people, the chapter Formal caregivers' health characterization and self-perception: implications for long-term care practices, analyses the health perceptions of those professionals, highlighting that formal caregivers mainly perceive themselves as being physically overloaded. The need for interventions to prevent and alleviate physical and emotional overloads and promote strategies for self-care is stressed.

Home-villages as a residence and revitalization system of the territory presents the rationale that it is necessary to establish a land structure and intergenerational architecture able to minimize the isolation of the elderly population. Departing from the case study of Home-Village of São José de Alcalar, the authors appeal to the timeliness of the theme and the necessity to create workable answers that, despite concerns over accessibility and mobility needs for the aging population, are intended to be intergenerational.

Architecture for active learning and aging: towards open innovation in universities. This chapter underlines the critical role that architecture has to play in the evolution of universities towards excellence (building the "Educational Campus" paradigm) in order to achieve its true mission: "the integral formation of a human being". The author argues that through sound planning, universities can improve the nature of their spaces and invite citizens of all ages to keep on participating throughout their lives in the fascinating task of education.

The chapter Healthy aging: retirement and early retirement - organizations and human resource management intends to emphasize the 
demystification that the elderly person is a mere consumer of resources and that the concept of 'age management' must be part of the human resource management model in organizations. The importance of balance between the individual, work, environment and community and the need to look on the worker as a partner is also underlined.

The chapter Facilitators and barriers to active and healthy aging aims to address the advantages, opportunities and challenges, as well as limitations of International Classification of Functioning, Disability and Health within the context of its use by active aging researchers and agents, as a contribution to developing potential solutions to promote active aging.

Suicide after 65 years old: current data in Portugal points to a serious public health problem. The authors present the trends in rates of suicide in Portugal by gender and method used in aged people comparing to those less than 65 years old and argue that it is essential to develop prevention programs adapted to the needs of different risk groups.

Health education factsheet on mental health in the elderly reports on a study aimed at discussing some determinants of mental health in the elderly, relating them to mental health promotion programs and assessing their effectiveness. The findings led to the development of a document labelled as "Health education page" which contains information about the promotion of mental health in the elderly, which is intended to be a useful instrument for elderly people, caregivers, and professionals.

Aging, health and disease: the effect of religiosity on the optimism of elderly people points to the need to distinguish elderly people concerning an understanding of the factors that influence optimism. The study presents evidence, among other data, that the healthy elderly anchor their optimism in internality beliefs, while the ill elderly base their optimism on external factors.

Dispositional forgiveness and gratitude among older people refers to an empirical work that examines whether lasting resentment, sensitivity to circumstances, and unconditional forgiveness are present in older people and the relationships that they have with socio-demographic factors and with believing or not in god as well as attending church on a regular basis or not. 
The last chapter of this book is entitled Promoting active aging inside Portuguese residential institutions for the elderly: is there something missing? It contains a discussion about the importance of promoting active aging inside the residential institutions for the elderly based on the presentation of a research study carried out in eight institutions from the municipality of Coimbra, Portugal. Data showed that there is still a long way to go in order to effectively offer to institutionalized elders opportunities for participation, whether it involves experiences of learning and of personal development, or ordinary decisions related to their daily life as individuals and full citizens.

\section{References}

Arnett, J., \& Tanner, L. (2008). Emerging adults in America: Coming of age in the 21st century. Washington: American Psychological Association.

Baltes, P. B., \& Mayer, K. U. (1999). The Berlin aging study: Aging from 70 to 100. Cambridge: Cambridge University Press.

Council of Europe (1970). Lifelong education: A compendium of discussion. Strasbourg.

Dave, E. (1976/1979). Fundamentos de la educación permanente. Madrid: Santillana.

De Natale, M. L. (2003). La edad adulta: Una nueva etapa para educarse. Madrid: Narcea.

Dias, J. D. (2012). O contributo dos cursos de Educação e Formação de Adultos para a (re) integração social: Um estudo realizado no Centro Educativo dos Olivais. Dissertação de mestrado não publicada. Coimbra: Faculdade de Psicologia e de Ciências da Educação.

Faure, E., Herrera, F., Kaddoura, A-R., Lopes, H., Petrovski, A. V., Rahnema, M., \& Ward, F. C. (1972). Apprendre à être. Paris: UNESCO.

Ferreira, J., \& Jorge, A. (2008). Para a compreensão da adultez emergente em Portugal. Psychologica, 48, 159-166.

Legrand, P. (1969). The meaning of lifelong education. Paris: UNESCO.

Lima, L. C. (2010a). A educação faz tudo? Crítica ao pedagogismo na "sociedade de aprendizagem". Revista Lusófona de Educação, 15, 41-54.

Lima, L. C. (2011). António Simões, um académico pioneiro da educação permanente e de adultos em Portugal. In L. Alcoforado, J. A. Ferreira, A. G. Ferreira, M. P. Lima, C. Vieira, A. L. Oliveira \& S. M. Ferreira, Educação e formação de adultos: Políticas, práticas e investigação (pp. 21-28). Coimbra: Imprensa da Universidade de Coimbra.

Lima, M. P. (2010b). Envelhecimento(s): Estado da arte. Coimbra: Imprensa da Universidade de Coimbra.

OECD (1973). Recurrent education: A strategy for lifelong learning. Paris.

Oliveira, A. L. (2005). Aprendizagem autodirigida: Um contributo para a qualidade do ensino superior. Dissertação de doutoramento. Universidade de Coimbra: Faculdade de Psicologia e de Ciências da Educação. 
Oliveira, A. L., Vieira, C., Lima, M. P., Nogueira, S., Alcoforado, L., Ferreira, J. A., \& Zarifis, G. (2011). Developing instruments to improve learning and development of disadvantage seniors in Europe: The paladin project. In Pixel (Ed.), Conference proceedings of the International Conference The Future of Education (vol. 1, pp. 268-274). Florence: Simonelli Editore.

Osório, A. R. (2005). Educação permanente e educação de adultos. Lisboa: Instituto Piaget.

Paúl, C., \& Ribeiro, O. (2012). Introdução. In Manual de gerontologia: Aspetos biocomportamentais, psicológicos e sociais do envelhecimento (pp. XVII-XX). Lisboa: Lidel.

Poon, L. W. et al. (2007). Methodological considerations in studying centenarians. Annual Review of Gerontology and Geriatrics, 27, 231-264.

Riemen, R. (2011). Nobreza de espírito: Um ideal esquecido. Lisboa. Editorial Bizâncio.

Schaie, K. W. (1996). Human development: Aging. In A. C. Tuijnman (Ed.), International encyclopedia of adult education and training (pp. 348-353). Oxford: Pergamon.

Schwartz, B. (1973). L'Education demain: Une etude de la Fondation Européenne de la Culture. Paris: Aubier Montaigne.

Sherron, R. H., \& Lumsden, D. B. (1978). Introduction to educational gerontology. Washington: Hemisphere Publishing Corporation.

Simões, A. (1979a). O adulto em perspectiva: Diferenças de comportamento associadas à idade. Revista Portuguesa de Pedagogia, XIII, 3-66.

Simões, A. (1979b). Educação permanente e formação de professores. Coimbra: Livraria Almedina.

Simões, A. (1990). Alguns mitos respeitantes aos idosos. Revista Portuguesa de Pedagogia, XXIV, 109-121.

Simões, A. (1999). A educação dos idosos: Uma tarefa prioritária. Revista Portuguesa de Educação, 12(2), 7-27.

Simões, A. (2002). Um novo olhar sobre os idosos. Revista Portuguesa de Pedagogia, 36(1, 2 e 3), 559-569.

Simões, A. (2006). A nova velhice: Um novo público a educar. Porto: Ambar.

Vieira, C. C., \& Perista, H. (2012). Nota de Abertura. Para uma compreensão genderizada do processo de envelhecimento. Ex Aequo, 26, 9-11.

Zarifis, G., \& Gravani, M. (Eds.).(2014). Challenging the 'European Area of Lifelong Learning': A critical response. London: Springer. 